\title{
Age-Dependent Variations of Lysosomal Enzymes in Human Liver
}

\author{
Ryoji Mrnami, Shigeo Sato, Tooru Kudoh, Kazuhiko \\ Oyanagi and Tooru Nakao \\ Department of Pediatrics, Sapporo Medical College, Sapporo \\ 060
}

\begin{abstract}
Minami, R., Sato, S., Kudoh, T., Oyanagi, K. and Nakao, T. AgeDependent Variations of Lysosomal Enzymes in Human Liver. Tohoku J. exp. Med., 1979, 129 (1), 65-70 — The specific activities, the $\mathrm{Km}$ values, and the elution patterns on DEAE 52 and Sephadex G-150 columns of six lysosomal enzymes in human liver during development were studied. The levels of total $\beta$-D. glucuronidase and $\mathrm{N}$-acetyl- $\beta$-D-glucosaminidase activities in childhood liver were higher than those in fetal liver. The $K m$ values of $\beta$-D-glucuronidase and $\beta$ - $\mathrm{D}$-galactosidase in fetal liver were about ten times higher than those in childhood liver. The elution patterns on DEAE 52 of $\beta$-D-glucuronidase and on Sephadex $\mathrm{G}-150$ of $\alpha$-D- and $\beta$-D-galactosidases changed with aging. It is suggested that lysosomal enzymes related to degradation of gangliosides and glycosaminoglycans change during development. —_ lysosomal enzyme; fetal liver; childhood liver
\end{abstract}

Up to now, studies on developmental patterns of lysosomal enzymes in human tissues have been found in only a few reports (Harzer and Sandhoff 1971; Scott et al. 1971; Antonowicz et al. 1974; Alhadeff et al. 1975). Some of lysosomal enzymes participate in the degradation of gangliosides, glycosaminoglycans and glycoproteins. Therefore, lysosomal enzyme deficiencies result in accumulations of these respective substances in tissue. Furthermore, some enzymes exist in isoenzyme forms and some isoenzyme patterns appear to change during development (Harzer and Sandhoff 1971; Alhadff et al. 1975).

In this study, we have examined the specific activities, the $\mathrm{Km}$ values, and the elution patterns on DEAE 52 and Sphadex G-150 columns of six lysosomal enzymes in liver materials derived from fetuses and children; i.e., $\alpha$-D-mannosidase, $\beta$-D-glucuronidase, $\beta$-D-galactosidase, $\beta$-D-glucosidase, $\alpha$-D-galactosidase and $\mathrm{N}$-acetyl-R-D-glucosaminidase.

\section{Materials and Methods}

Enzyme preparations. Fetal livers between 16 and 20 weeks of gestation were obtained from therapeutic abortion for psychosocial reasons. Childhood livers between 1 and 7 years of age were obtained from autopsies of patients who had neither evidence of liver diseaes, nor treatment of steroid and antineoplastic agents. The livers were stored

Received for publication, September 14, 1978. 
at $-70^{\circ} \mathrm{C}$ until analysis. Frozen pieces of liver were homogenized in 10 volumes of ice-cold water. The homogenate was sonicated for 1 min using an isonator (Kubota model $200 \mathrm{M}$ ) and centrifuged at $100,000 \times \mathrm{g}$ for $60 \mathrm{~min}$. The supernatant served as an enzyme source.

Materials. 4-Methylumbelliferyl (4-MU) derivatives of $\alpha$-D-mannopyranoside, $\beta$-Ddeoxy-glucuronide trihydrate, $\quad \beta$-D-galactopyranoside, $\quad \beta$-D-glucopyranoside, $\alpha$-Dgalactopyranoside and 2-acetamide-2-deoxy- $\beta$-D-glucopyranoside were obtained from KochLigh Laboratories (England).

Incubation mixtures for enzyme assay. $\alpha$-D-Mannosidase: $0.4 \mathrm{ml}$ of enzyme sample, $1.0 \mathrm{ml}$ of $1 \mathrm{mM} 4-\alpha$-D-mannopyranoside and $1.0 \mathrm{ml}$ of $0.1 \mathrm{M}$ Mellvaine phosphate-citrate buffer of appropriate $\mathrm{pH}$ (Phillips et al. 1974).

$\beta$-D-Glucuronidase: $0.2 \mathrm{ml}$ of enzyme sample, $0.1 \mathrm{ml}$ of $1 \mathrm{mM} 4-\mathrm{MU}$ - $\beta$-glucuronide trihydrate and $0.7 \mathrm{ml}$ of $0.1 \mathrm{M}$ Mcllvaine buffer (Mead et al. 1955).

$\beta-\mathrm{D}$-Galactosidase: $0.1 \mathrm{ml}$ of enzyme sample, $0.4 \mathrm{ml}$ of $0.8 \mathrm{mM}$ 4-MU- $\beta$-D-galacto. pyranoside containing $50 \mathrm{mM} \mathrm{NaCl}$ and $0.1 \mathrm{ml}$ of $0.1 \mathrm{M}$ Mcllvaine buffer (Öckermann 1968).

$\beta$-D-Glucosidase, $\alpha$-D-galactosidase and $\mathrm{N}$-acetyl- $\beta$-D-glucosaminidase: $0.1 \mathrm{ml}$ of enzyme sample, $0.1 \mathrm{ml}$ of $0.1 \mathrm{M}$ Mcllvaine buffer and $0.4 \mathrm{ml}$ of each $1 \mathrm{mM}$ 4-MU derivative (Ockermann 1968).

Enzyme assays. $\mathrm{pH}$ of the final assay mixtures for six lysosomal enzymes was as follows: $\alpha$-D-Mannosidase was assayed at $\mathrm{pH} 6.5, \beta$-D-glucuronidase at $\mathrm{pH} 5.0, \beta$-Dgalactosidase at $\mathrm{pH} 4.5, \beta$-D-glucosidase at $\mathrm{pH} 4.75, \alpha-\mathrm{D}$-galactosidase at $\mathrm{pH} 4.25$ and $\mathrm{N}$-acetyl- $\beta$-D-glucosaminidase at $\mathrm{pH}$ 4.5. Each incubation was carried out at $37^{\circ} \mathrm{C}$ for $60 \mathrm{~min}$. The reaction was stopped with $3 \mathrm{ml}$ of $0.25 \mathrm{M}$ glycine-carbonate buffer, $\mathrm{pH} 10.7$. The fluorescence was read immediately in a Hitachi spectrophotofluorometer (Model MPF4) with excitation wave-length $365 \mathrm{~nm}$ and emission wave-length $450 \mathrm{~nm}$. Protein was assayed as described by Lowry et al. (1956).

Ion-exchange chromatography. DEAE 52 was equilibrated in $10 \mathrm{mM}$ sodium phosphate buffer, $\mathrm{pH} 6.0$ and packed in a column $(0.8 \times 5.0 \mathrm{~cm})$. After the sample was applied to the column, $50 \mathrm{ml}$ of the equilibration buffer was eluted and the elution was continued with a linear $\mathrm{NaCl}$ gradient $(0-0.3 \mathrm{M})$ in $100 \mathrm{ml}$ of the same buffer. Fractions $(2 \mathrm{ml})$ were collected at a flow rate of $60 \mathrm{ml} / \mathrm{hr}$.

Gel filtration. The molecular size of each enzyme was investigated by using a column $(1.8 \times 85.0 \mathrm{~cm})$ of Sephadex G-150 equilibrated in $50 \mathrm{mM}$ sodium phosphate buffer, $\mathrm{pH} 7.0$. Fractions $(3.0 \mathrm{ml})$ were collected at a flow rate of $10 \mathrm{~m} / \mathrm{hr}$.

\section{Results}

Activity as a function of $p H$. The optimal $\mathrm{pH}$ values for the six lysosomal enzymes in fetal liver agreed with those in childhood liver (Fig. 1).

Michaelis constant. The apparent $\mathrm{Km}$ values for six the lysosomal enzymes tested were determined at their respective activity $\mathrm{pH}$ optima (Table 1). The $\mathrm{Km}$ values for $\alpha$-D-mannosidase, $\beta$-D-glucosidase, $\alpha$-D-galactosidase and $\mathrm{N}$-acetyl$\beta$-D-glucosaminidase in fetal liver were similar to those in childhood liver. However, the $\mathrm{Km}$ values of $\beta$-D-glucuronidase and $\beta$-D-galactosidase in fetal liver were about ten times higher than those in childhood liver and these differences were statistically significant.

Total specific activities. As shown in Table 2 and Fig. 2, the levels of total specific activities of $\alpha$-D-mannosidase, $\beta$-D-glucuronidase, $\alpha$-D-galactosidase, and $\mathrm{N}$ acetyl- $\beta$-D-glucosaminidase were higher in childhood liver than in fetal liver. Especially, $\beta$-D-glucuronidase and $N$-acetyl- $\beta$-D-glucosaminidase activities increased significantly in childhood liver, whereas $\beta$-D-galactosidase and $\beta$-D-glucosidase showed similar total specific activities in both fetal and childhood livers. 

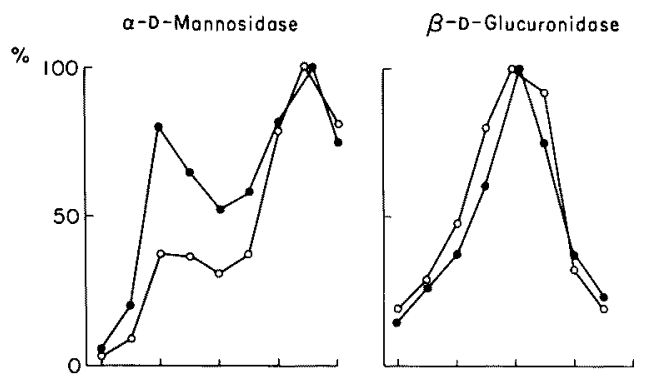

$\beta-D-G o l a c t o s i d o s e$
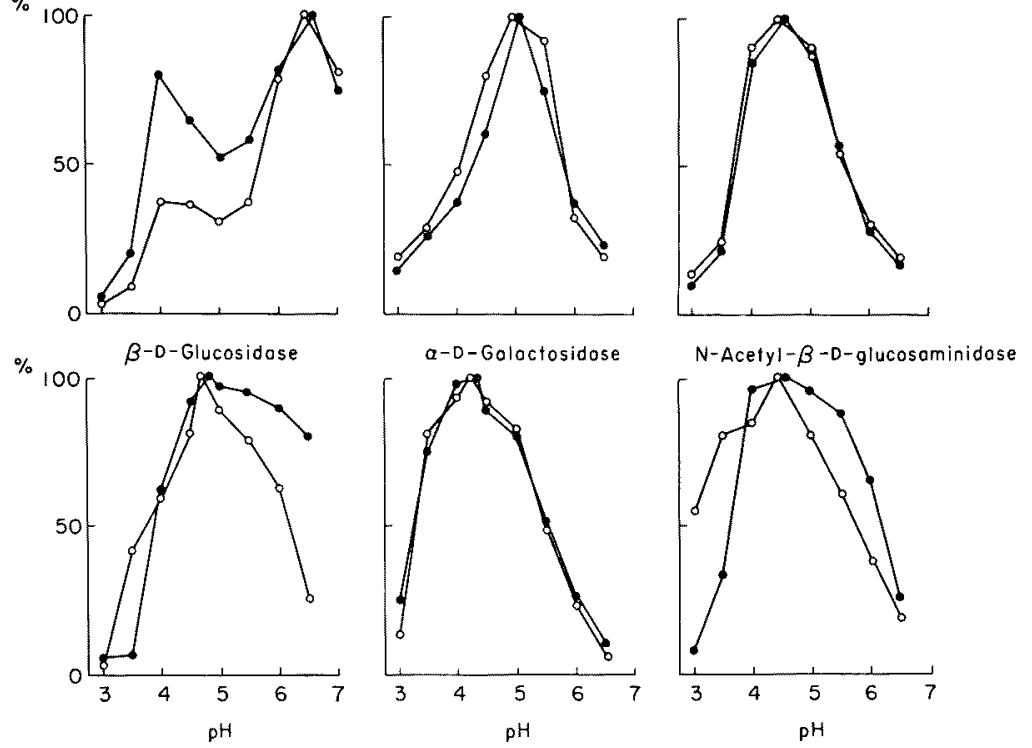

Fig. 1. Effect of $\mathrm{pH}$ on six lysosomal enzymes in livers from fetus and child. $\circ-0$, childhood liver; $\bullet-\bullet$, fetal liver.

TABLE 1. Comparison of apparent $K m$ values for six lysosomal enzymes in livers from fetus and child

\begin{tabular}{lrc}
\cline { 3 - 3 } \multicolumn{1}{c}{ Enzyme } & \multicolumn{2}{c}{ Km value $(\mathrm{M})$} \\
\cline { 2 - 3 } & Fetal liver & Childhood liver \\
\hline & $5.6 \times 10^{-4}$ & $8.4 \times 10^{-4}$ \\
$\alpha$-D-Mannosidase & $26.7 \times 10^{-4}$ & $2.3 \times 10^{-4}$ \\
$\beta$-D-Glucuronidase & $26.7 \times 10^{-4}$ & $2.3 \times 10^{-4}$ \\
$\beta$-D-Galactosidase & $8.7 \times 10^{-5}$ & $8.7 \times 10^{-5}$ \\
$\beta$-D-Glucosidase & $3.3 \times 10^{-4}$ & $1.0 \times 10^{-3}$ \\
$\alpha$-D-Galactosidase & $6.7 \times 10^{-3}$ & $6.3 \times 10^{-4}$ \\
N-Acetyl- $\beta$-D-glucosaminidase & & \\
\hline
\end{tabular}

TABLE 2. Activity of six lysosomal enzymes in livers from fetus and child

\begin{tabular}{|c|c|c|}
\hline Enzyme & $\begin{array}{c}\text { Fetal liver } \\
(n=8)\end{array}$ & $\begin{array}{l}\text { Childhood liver } \\
\qquad(n=10)\end{array}$ \\
\hline$\alpha$-D-Mannosidase & $\begin{array}{c}17.3 \\
(11.5 \sim 21.5)\end{array}$ & $\left(\begin{array}{c}38.4 \\
(10.5 \sim 85.7)\end{array}\right.$ \\
\hline$\beta$-D-Glucuronidase & $\begin{array}{c}5.0 \\
(1.3 \sim 9.8)\end{array}$ & $\begin{array}{c}52.6 \\
(37.0 \sim 89.0)\end{array}$ \\
\hline$\beta$-D-Galactosidase & $\begin{array}{c}152.9 \\
(16.0 \sim 329.0)\end{array}$ & $\begin{array}{c}154.5 \\
(45.5 \sim 332.0)\end{array}$ \\
\hline$\beta \cdot \mathrm{D}-$ Glucosidase & $\begin{array}{c}8.7 \\
(2.0 \sim 13.8)\end{array}$ & $\left(2.0 \sim^{8.4} 15.0\right)$ \\
\hline$\alpha$-D-Galactosidase & $\begin{array}{c}27.1 \\
(7.8 \sim 52.8)\end{array}$ & $\begin{array}{c}56.9 \\
(20.2 \sim 100.8)\end{array}$ \\
\hline N-Acetyl- $\beta$-D-glucosaminidase & $\begin{array}{c}141.7 \\
(73.4 \sim 224.7)\end{array}$ & $\begin{array}{c}794.8 \\
(390.4 \sim 1105.0)\end{array}$ \\
\hline
\end{tabular}

Activity was expressed as nmoles per mg protein per hr. 

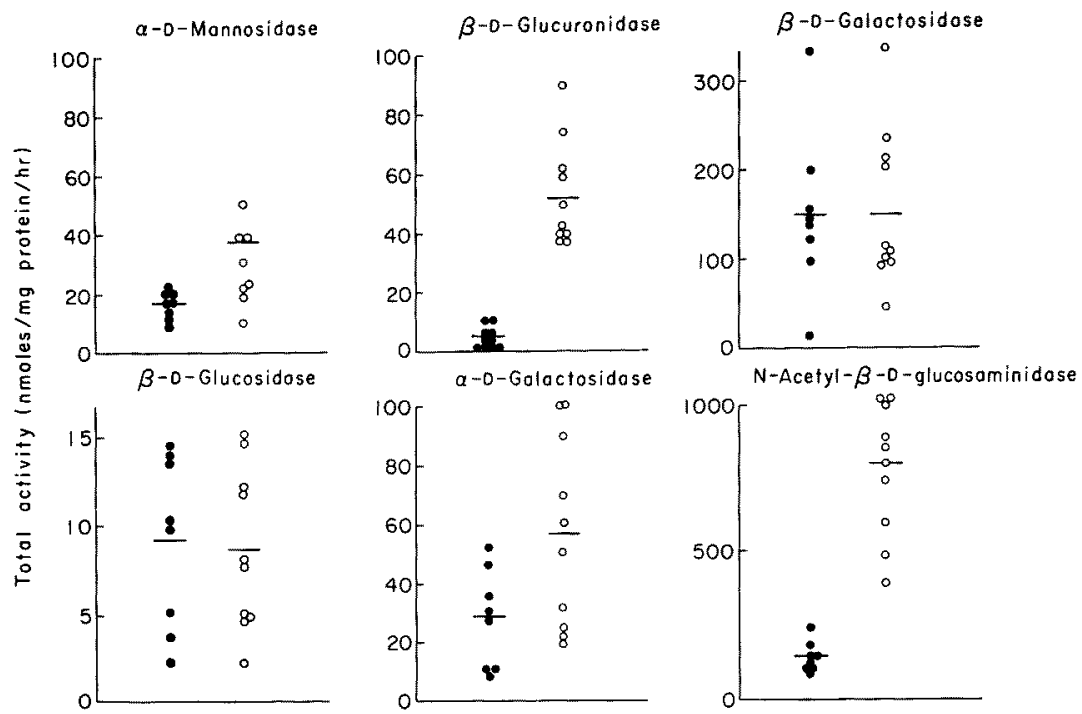

Fig. 2. Total activities of six lysosomal enzymes in livers from fetus and child. $\circ$, childhood liver; $\bullet$, fetal liver; - , mean
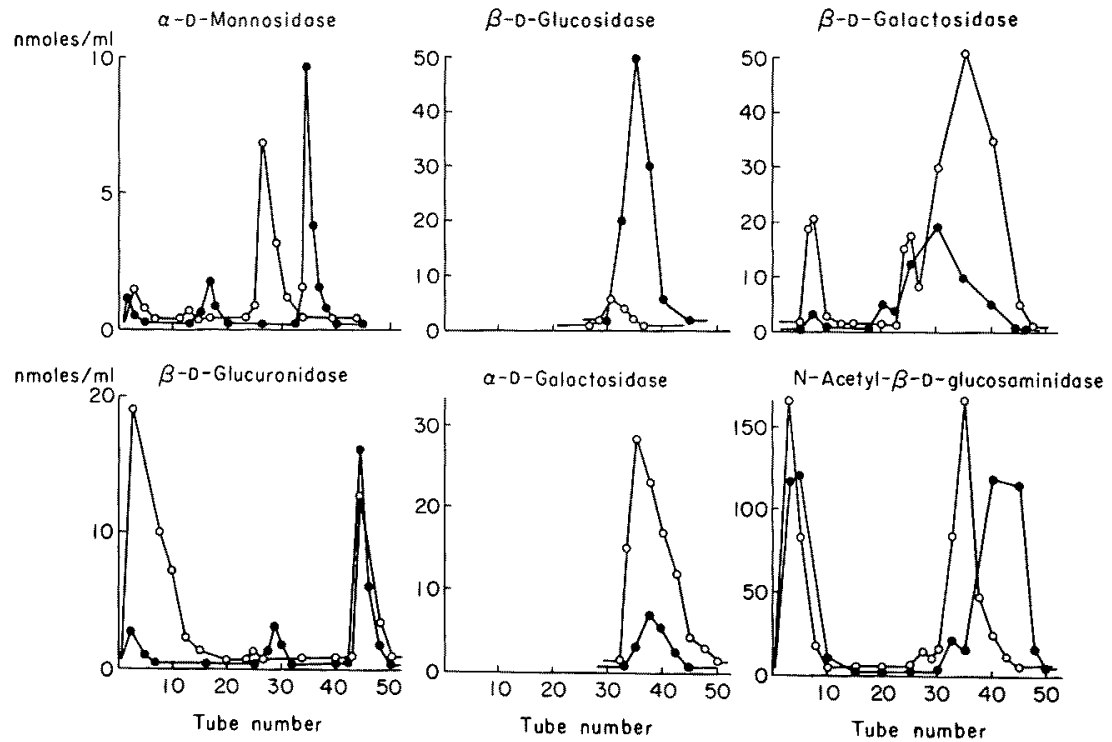

Fig. 3. DEAE 52 chromatography of six lysosomal enzymes in liver from fetus and child. $\circ-0$, childhood liver; - $\bullet$, fetal liver.

Ion-exchange chromatography on DEAE 52. As shown in Fig. 3, the elution profiles of $\alpha$-D-mannosidase, $\beta$-D-galactosidase, $\beta$-D-glucosidase, $\alpha$-D-galactosidase and $\mathrm{N}$-acetyl- $\beta$-D-glucosaminidase in fetal liver showed patterns similar to those in childhood liver. $\beta$-D-Glucuronidase was separated into three peaks in both fetal 
and childhood livers, although the first peak in childhood liver was markedly higher than that in fetal liver.

Gel filtration on Sephadex G-150. As shown in Fig. 4, the elution patterns of all lysosomal enzymes tested except for $\alpha$-D- and $\beta$-D-galactosidases were similar in both fetal and childhood livers. In the elution patterns of $\beta$-Dgalactosidase, three fractions were observed for both fetal and childhood livers. In childhood liver the second fraction (acidic $\beta$-D-galactosidase) was higher than the third fraction (neutral $\beta$-D-galactosidase). On the other hand, in fetal liver the second fraction was significantly lower. Only one fraction was observed in fetal liver $\alpha$-D-galactosidase, whereas two fractions were observed in childhood liver.

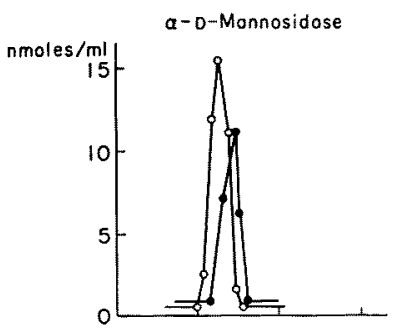

$\beta$-0-Glucosidase
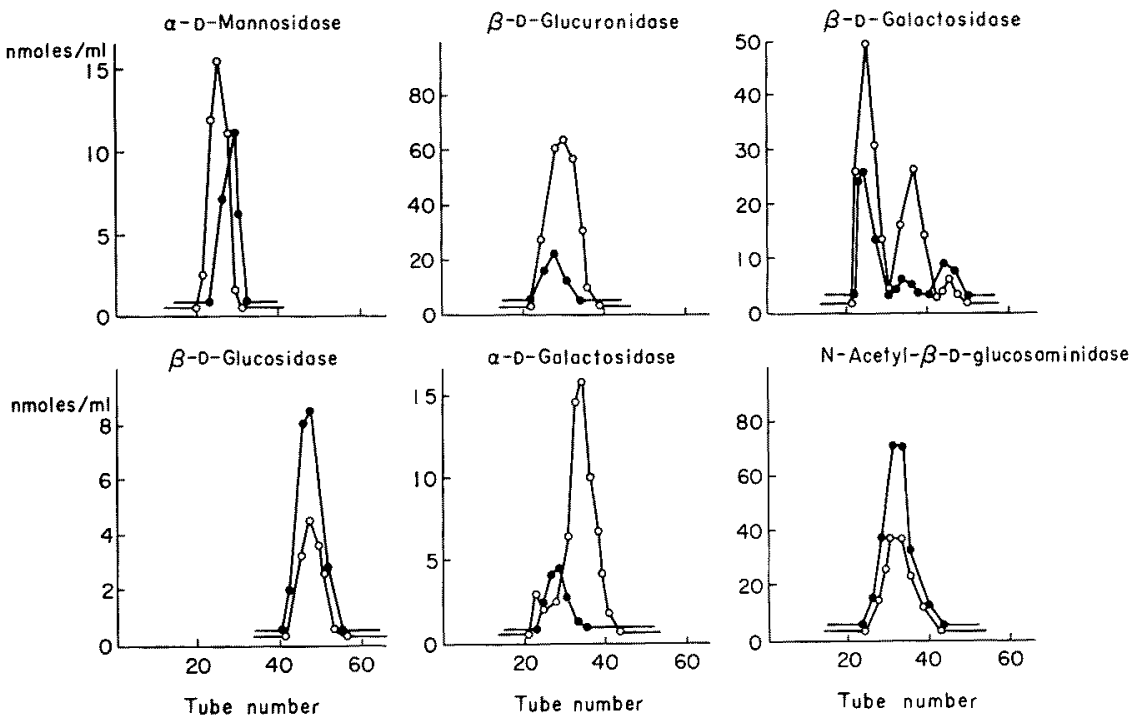

Fig. 4. Gel filtration on Sephadex G-150 of six lysosomal enzymes in livers from fetus and child.

○-o, childhood liver; $\bullet-\bullet$, fetal liver.

\section{Discussion}

Scott et al. (1971) described that the specific activities and isoenzyme pattern of lysosomal enzymes obtained from fetal liver were similar to those from childhood liver. On the other hand, Harzer and Sandhoff (1971) observed that the toal $\mathrm{N}$-acetyl- $\beta$-D-hexosaminidase activity of human brain increased with aging, and that the ratio between the hexosaminidases $\mathrm{A}$ and $\mathrm{B}$ changed during life by the reason of enzyme-substrate-parallelism. Furthermore, Alhadeff et al. (1975) reported that the isoenzyme pattern of $\alpha$-L-fucosidase in human liver appeared to change by sialylation of neutral form of $\alpha$-L-fucosidase during development as well. The present studies showed that the total activities of $\alpha$-D-glucuronidase and $\mathrm{N}$ acetyl- $\beta$-D-glucosaminidase increased, the $\mathrm{Km}$ values of $\beta$-D-glucuronidase and $\beta$-D- 
galactosidase changed, and the elution patterns on DEAE 52 of $\beta$-D-glucuronidase and on Sephadex G-150 of $\alpha$-D- and $\beta$-D-galactosidases changed with aging. These lysosomal enzymes are related to degradation of gangliosides and glycosaminoglycans. Moreover, Harzer and Sandhoff (1971) reported parallelism between hexosaminidase activity and the level of gangliosides in human liver. Hsu and Tappel (1965) also described parallelism between the concentration of glycosaminoglycans in the gastrointestinal tract and the specific activities of arylsulfatase, $\beta$ glucuronidase, and $\beta$-galactosidase in the mature rat and pig.

It is therefore suggested that some lysosomal enzymes in human liver, especially enzymes related to degradation of gangliosides and glycosaminoglycans, change during development in accord with other reports (Harzer and Sandhoff 1971; Slhadeff et al. 1975), although our data were too limited for any definite conclusion.

\section{References}

1) Alhadeff, J.A., Tennant, L. \& O'Brien, S.S. (1975) Isoanzyme patterns of human liver $\alpha$-L-fucosidase during development. Develop. Biol., 47, 319-324.

2) Antonowicz, I., Chang S.K. \& Grand, J.R. (1974) Development and distribution of lysosomal enzymes and disaccharidases in human fetal intestine. Gastroenterology., 67, $51-58$.

3) Harzer, K. \& Sandhoff, K. (1971) Age-dependent variations of the human N-acetyl- $\beta$ D-hexosaminidases. J. Neurochem., 18, 2041-2050.

4) Hsu, L. \& Tappel, A.L. (1965) Lysosomal enzymes and mucopolysaccharides in the gastrointestinal tract of the rat and pig. Biochim. biophys. Acta. (Amst.), 101, 83-89.

5) Lowry, O.H., Rosebrough, N.J., Farr, A.L. \& Randall, R.J. (1956) Protein measurement with the folin phenol reagent. J. biol. Chem., 193, 265-275.

6) Mead, J.A., Smith, J.N. \& Williams, R.T. (1955) The biosynthesis of the glucuronidase of umbelliferone and 4-methylumbelliferone and their use in fluorimetric determination of $\beta$-glucuronidase. Biochem. $J ., 61,569-574$.

7) Ockermann, P.A. (1968) Identity of $\beta$-glucuronidase, $\beta$-xylosidase and one of the $\beta$ galactosidase activities in human liver when assayed with 4-methylumbelliferyl- $\beta$-Dglycosides. Biochem. biophys. Acta (Amst.), 165, 59-62.

8) Phillips, N.C., Robinson, D. \& Winchester, B.G. (1974) Human liver $\alpha$-D-mannosidase activity. Clin. chim. Acta., 55, 11-19.

9) Scott, C.R., Clark, S.H. \& O'Brien, J.S. (1971) Early lysosomal enzyme expression in fetal liver. In: Abstracts of Papers Presented, 4th International Congress of Human Genetics (Excepta Medica International Congress Series No. 233). Excepta Medica, Amsterdam, pp. 162-163. 